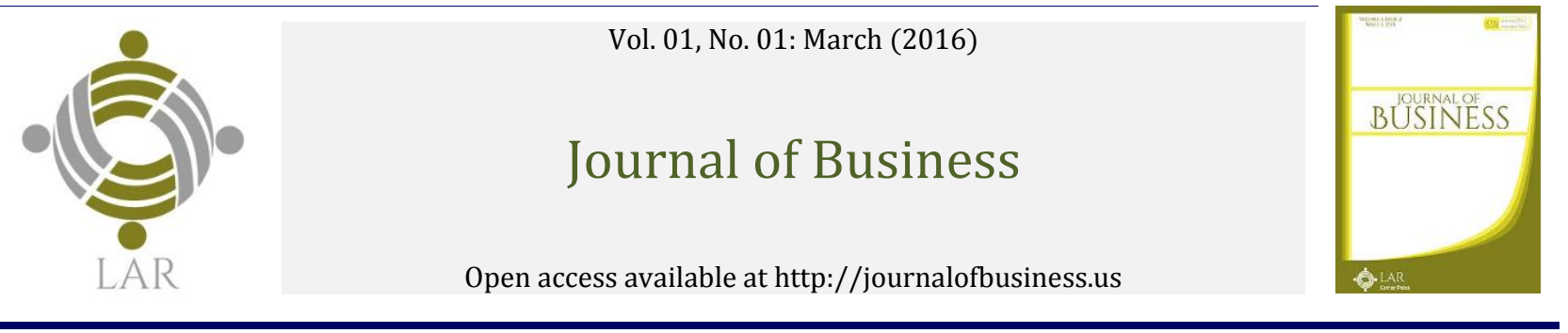

\title{
"Vicarious" Liability of the Employer in Sexual Harassment Cases: A Comparative Study
}

\author{
Dr DM Smita*, DJ Viviers ${ }^{b}$ \\ a DM Smit, B Iur, LLB, LLM (cum laude), LLD, lecturer, Department of Mercantile Law and Centre for Labour Law, University of \\ the Free State. \\ b D Viviers, LLB (cum laude), LLM (Cum Laude) Department of Mercantile Law, University of the Free State. \\ * Correspondence concerning this article should be addressed to DM Smit. E-mail smitdm@ufs.ac.za.
}

\section{A R T I C L E I N F O}

Received: 06-12-2015

Accepted: 16-01-2016

Available online: 20-03-2016

Keywords:

sexual harassment, vicarious liability, damages, delict, workplace, labour law.

JEL Classification: J380, J710, J780, M510

\section{A B S T R A C T}

In recent years, sexual harassment in the workplace has drastically increased worldwide, including in South Africa. Consequently, the country's courts have looked to protect employees by attaching obligations to employers that could render them liable when their employees are sexually harassed in the workplace. The Employment Equity Act and the Code of Good Practice on the Handling of Sexual Harassment Cases in the Workplace have also introduced measures in terms of which an employer may be held liable once certain requirements have been met. However, when compared to other jurisdictions such as the United States of America, Australia and Ontario, Canada, where the legal position on sexual harassment in the workplace and employers' vicarious liability seems clear-cut and effective, the South African measures seem to lack teeth. Various loopholes, poor awareness and training as well as lacking implementation mean that employees who are sexually harassed in employment may find themselves unprotected and unable to hold their employer vicariously liable. In an attempt to contribute to the development of South African law in this regard, this article firstly provides an overview of the current position in South Africa, followed by a comparative overview of the law in the USA, Australia and Ontario, Canada. It is concluded that South Africa stands to learn valuable lessons from these jurisdictions' approach to sexual harassment in employment. The most significant of these include the proposed establishment of a body similar to the USA' s Equal Employment Opportunity Commission or the Australian Human Rights Commission, which can be tasked specifically to deal with employment issues, including protecting employees against harassment, and enforcing and raising awareness about employer liability; making the drafting of internal policies on sexual harassment in employment compulsory and subject to inspection, and instituting compulsory training for managers to prevent and deal with sexual harassment in the workplace.

This is an open access article under the terms of the Creative Commons Attribution License 4.0, which allows use, distribution and reproduction in any medium, provided the original work is properly cited.

\section{$1.0 \quad$ Introduction}

Sexual harassment is a major societal problem, especially in the workplace, where it affects both male and female employees. ${ }^{1}$ In recent times, there has been a surge in workplace sexual harassment cases (Australian Human

\footnotetext{
1 The majority of those affected are female.
} 
Rights Watch, 2008), ${ }^{2}$ although the prevalence of sexual harassment cannot be adequately measured by reference to case law alone, as many victims do not come forward (Mukheibir and Ristow, 2006, p. 245-246). South Africa has not escaped this phenomenon. One study reveals that $68 \%$ of women in South Africa are exposed to sexual harassment at least once in their lifetime, which could be regarded as an extrapolation of the broader violence problem in the country (Chicktay, 2010, p. 283). Consequently, the courts have looked to protect employees by attaching obligations to employers that could render them liable when their employees are sexually harassed in the workplace (Gule, 2005, p. 67). The Employment Equity Act (55 of 1998) ${ }^{6}$ has also introduced measures in terms of which an employer may be held liable for acts of sexual harassment committed by employees once certain requirements have been met, particularly section $60 .{ }^{7}$

This article sets out to explore the difference between, and the application of, common-law vicarious liability and statutory vicarious liability in cases of sexual harassment in the workplace. An investigation into the law on this issue in the United States of America (USA), Australia as well as Ontario, Canada, serves as the backdrop to recommendations made to the legal fraternity of South Africa on both the management of sexual harassment in employment and the enforcement of vicarious liability where sexual harassment occurs. The study is comparative and mainly consists of a review of literature on the chosen jurisdictions.

The paper firstly sets the scene with background on sexual harassment and employer liability as a legal problem in South Africa, referring to the common law as well as legislative provisions, including the Code of Good Practice on the Handling of Sexual Harassment Cases in the Workplace. A medley of relevant South African case law concludes the first section. This is followed by a discussion of the legal position in the USA, Australia and Ontario, Canada. Based on the comparison, the study finally proposes recommendations for the South African legal fraternity to consider.

First, however, it is for the sake of clarity necessary to highlight the distinction between common-law vicarious liability and statutory employer liability (established in section 60 of the Employment Equity Act). ${ }^{8}$ In the context of sexual harassment, vicarious liability generally means that if an employee is harassed in the workplace, the employer in charge of such workplace may be held liable. The word "vicarious" originated in the mid-17th century and is derived from the Latin word "vicarius", which means "substitute" (Oxford Dictionaries, 2014). Although an attempt is made throughout this article to maintain the distinction between statutory employer liability and common-law vicarious liability, the focus is on the broad concept of "vicarious/substitute " mentioned above, since the study is primarily concerned with employer liability for acts of sexual harassment it did not sanction.

Various reasons have been put forward to justify the existence of vicarious liability. Fleming (in Calitz, 2005, p. 215) for example states:

[T [ he modern doctrine of vicarious liability cannot parade as a deduction from legalistic premises but should be recognised as being based on a combination of policy considerations, the most important of which is the belief that a person who employs others to advance his own economic interest should in fairness be placed under a corresponding liability for losses incurred in the course of the enterprise.

In one of the most influential sexual harassment cases in South African labour law, Grobler v Naspers (2005), an employer was held to be vicariously liable for sexual harassment perpetrated by one of its employees, while the employer was found to be directly liable in the appeal case, Media 24 v Grobler (2005). In Piliso v Old Mutual Life Assurance Co (2007), an employer was held liable to pay constitutional damages to an employee for a violation of her constitutional right to fair labour practices, as the employer failed to provide a safe working environment to an employee who had been sexually harassed by a non-employee. In addition, section 6(3) of the Employment Equity Act (55 of 1998; Chicktay, 2010, p. 292) states that harassment of an employee on one or more of the grounds mentioned in the act amounts to unfair discrimination, which also includes sexual harassment.

Although legislation, particularly the Employment Equity Act (55 of 1998), ${ }^{15}$ has gone a long way to address sexual harassment in the workplace, it exists in conjunction with the common-law doctrine of vicarious liability, in terms

2 A 2008 Australian survey found that $22 \%$ of women and 5\% of men aged 18-64 had experienced sexual harassment in the workplace in their lifetime, compared to $28 \%$ of women and $7 \%$ of men in 2003. Around one in three women in Australia aged 18-64 experiences sexual harassment in their lifetime. The majority of sexual harassment continues to be experienced in the workplace (65\%). Nearly half of those who were sexually harassed in the five years prior to the study reported that it had also happened to someone else in the same workplace.

6 Along with the Employment Equity Amendment Act 47 of 2013.

7 Although this liability is subject to certain limitations, which is elaborated on below.

8 This distinction is illustrated under paragraph 2.0 below.

15 As amended by Act 47 of 2013. 
of which an employer may be held liable for acts of sexual harassment committed by its employees. The following section provides an overview of the development of employer liability in sexual harassment cases, and illustrates the evolution of the common law and labour legislation in this regard, as well as the interpretation and application of this concept by the South African judicial forums. It also explores the reasons for the implementation of the doctrine of vicarious liability for workplace sexual harassment, its effects, and its impact on individuals and society in general.

\subsection{Vicarious liability in South African law}

\subsection{Origins and the common-law doctrine of vicarious liability}

The doctrine of vicarious liability originates from the law of torts. Generally in tort law, a person is held liable for damages suffered as a result of a tort that he has authorised. In the case of vicarious liability, however, a person is held liable for the torts of another, without having consented to them (Law Teacher, n.d.). Atiyah (1967, p. 3) describes this as follows:

Vicarious liability in the law of tort may be defined as a liability imposed by the law upon a person as a result of (1) a tortious act or omission by another, (2) some relationship between the actual tortfeasor and the defendant whom it is sought to make liable, and (3) some connection between the tortious act or omission and that relationship.

While the historical or jurisprudential origins of this liability are not entirely clear (Botha and Millard, 2012, p. 227),18 it has been entrenched in common law for centuries. Even though this principle deviates from the normal liability for wrongdoing, the common law has continued to develop and rely on vicarious liability to such an extent that it is generally assumed that any complete theory of tort law must be able to account for its presence (Neyers, 2005 , p. 2). Several reasons have been suggested for the existence of this doctrine, including that a victim should be entitled to "fair and just compensation" from the employer' s more extensive resources, and that an employer will be more proactive in deterring employees from causing damage if there is a possibility that they may be held liable for it (Calitz, 2005, p. 215).

The doctrine of vicarious liability is largely based on English law. More particularly, it is based on the so-called Salmond rule, which states that the master is responsible for the wrongful acts authorised by him and:

... is liable even for acts which he has not authorized provided they are so connected with the acts which he has authorized that they may rightly be regarded as modes, although improper modes, of doing them. On the other hand, if the unauthorized and wrongful act ... is not so connected with the authorized act as to be a mode of doing it but is an independent act, the master is not responsible, for in such a case the servant is not acting in the course of his employment, but has gone outside it. (Atiyah, 1967, p. 175; Calitz, 2005, p. 217)

Also, in the matter of Mkhize vs Martins (1914; Calitz, 2005, p. 217), appeal judge Innes stated:

[W] e may, for practical purposes, adopt the principle that a master is answerable for the torts of his servant committed in the course of his employment, bearing in mind that an act done by a servant solely for his own interests and purposes, and outside his authority, is not done in the course of his employment, even though it may have been done during his employment.

The South African common-law doctrine of vicarious liability is developed by the judiciary, and as such, has filtered into the realm of workplace sexual harassment. The Constitutional Court in $K v$ Minister of Safety and Security (2005, at 21) described vicarious liability as follows:

The common-law principles of vicarious liability hold an employer liable for the delicts committed by its employees where the employees are acting in the course and scope of their duty as employees. The principles ascribe liability to an employer where its employees have committed a wrong but where the employer is not at fault.

Neethling and colleagues (2010, p. 365) describe vicarious liability as "the strict liability of one person for the delict of another", which arises from a particular relationship between such persons. One such relationship is that of employment. In order to prove the employer's vicarious liability in sexual harassment cases, one has to demonstrate that the perpetrator employee was in fact acting within the scope of his/her employment when the harassment took place (Gule, 2005, p. 67). Other requirements are that there must have been an employment

18 This doctrine is said to have been borrowed from English law. 
relationship at the time when the sexual harassment was committed, the perpetrator employee must have acted unlawfully, and the act must have led to a third person suffering damages (Calitz, 2005, p. 216; Neethling, Potgieter and Visser, 2010, p. 366-371). The Constitutional Court in F V Minister of Safety and Security (2013, at 14) endorsed Neethling and colleagues' view of vicarious liability.

It is not a requirement that the employer be at fault, and it therefore constitutes a form of strict liability (Neethling et al., 2010, p. 365). Neethling and colleagues (2010, p. 366) explain that this rationale stems from the fact that the work with which an employee is entrusted creates certain possibilities of harm (the commission of delicts) for which an employer ought to be held liable on the basis of "fairness and justice" for the injuries sustained by third parties. The Constitutional Court supported this as follows in K v Minister of Safety and Security (2005, at 24):

It is clear, therefore, that there is a deep-seated sense of justice that is served by the notion that in certain circumstances a person in authority will be held liable to a third party for injuries caused by a person falling under his or her authority.

The Constitutional Court in $F_{V}$ Minister of Safety and Security (2013, at 45) provided the following explanation for the rationale behind the doctrine of vicarious liability:

... employees are extensions of their employers. This is indeed so because, figuratively, employees are the hands through which employers do their work. Employers could therefore be held to have created a risk harm to others should their employees prove to be inefficient or untrustworthy. That potential risk imposes an obligation on employers to ensure that the employees they hold out as the hands through which they would serve or do business with others, would not do the opposite of what they are instructed and obliged to do. Should they, however, act inconsistently with the employer's core business, some link between the employers' business and the delictual conduct must be established before the employers may be held vicariously liable.

Neethling (2011, p. 190) also confirms that employers create a risk that their employees may not be trustworthy, or may even be dishonest or criminal, and as such may seek to exploit their employment position for their own ends. In F V Minister of Safety and Security (2013, at 41), the Constitutional Court also clarified the two tests available to determine vicarious liability. These are the so-called "standard test" and "deviation test". The court described them as follows:

Two tests apply to the determination of vicarious liability. One applies when an employee commits the delict while going about the employer's business. This is generally regarded as the 'standard test'. The other test finds application where wrongdoing takes place outside the course and scope of employment. These are known as 'deviation cases'.

\subsection{Statutory employer liability: The Employment Equity Act and the new amendments thereto}

As the prevalence of sexual harassment in the workplace continued to escalate, the need to implement legal measures to hold employers liable, as a means of compelling them to introduce more stringent policies and measures to try and curb this problem in the workplace, became evident. Not only do harassed employees suffer from stress-related illnesses, but employers carry costs associated with absenteeism, replacement labour, legal costs and reduced productivity (Chicktay, 2010, p. 284). Chicktay (2010, p. 284) refers to the prevalence of headaches, loss of concentration, increased workloads where job vacancies exist, and the demotion or dismissal of employees due to the effects of sexual harassment at work.

As common-law remedies are limited to the payment of damages for harm already caused, it became evident that legislative intervention was needed in order to prevent sexual harassment and govern such disputes proactively and effectively (Du Toit and Potgieter, 2014, p. 33). The legislature addressed this issue by including harassment in the framework of the Employment Equity Act (55 of 1998), while the Department of Labour published a Code of Good Practice on the Handling of Sexual Harassment Cases in the Workplace (GN 1367 of 1998), as well as subsequent amendments thereto (GN 1357 of 2005). The following sections of the Employment Equity Act (as amended) make up the primary statutory framework in relation to sexual harassment in the workplace and employer liability:

Section 5 of the Employment Equity Act places an obligation on employers to promote equal opportunity in the workplace by eradicating unfair discrimination and eliminating it from their employment policies and practices. Section 6(1) of the Employment Equity Act contains the following prohibition on unfair discrimination: 
No person may unfairly discriminate, directly or indirectly, against an employee, in any employment policy or practice, on one or more grounds, including race, gender, sex, pregnancy, marital status, family responsibility, ethnic or social origin, colour, sexual orientation, age, disability, religion, HIV status, conscience, belief, political opinion, culture, language and birth or on any other arbitrary ground.

Section 6(3) of the Employment Equity Act states that "[h]arassment of an employee is a form of unfair discrimination and is prohibited on one, or a combination of grounds of unfair discrimination listed in subsection (1)". Section 60 of the Employment Equity Act provides the following requirements for holding an employer liable for the conduct of its employees:

1) If it is alleged that an employee, while at work, contravened a provision of this Act, or engaged in any conduct that, if engaged in by that employee's employer, would constitute a contravention of a provision of this Act, the alleged conduct must immediately be brought to the attention of the employer.

2) The employer must consult all relevant parties and must take the necessary steps to eliminate the alleged conduct and comply with the provisions of this Act.

3) If the employer fails to take the necessary steps referred to in subsection (2), and it is proved that the employee has contravened the relevant provision, the employer must be deemed also to have contravened that provision.

4) Despite subsection (3), an employer is not liable for the conduct of an employee if that employer is able to prove that it did all that was reasonably practicable to ensure that the employee would not act in contravention of this Act.

Du Toit and Potgieter (2014, p. 33) explain that harassment constitutes a blatant attack on the victim's dignity and, as such, falls under the prohibition of unfair discrimination mentioned above in order to safeguard the right to human dignity. Sexual harassment is regarded as the most prevalent form of harassment in the workplace (Du Toit and Potgieter, 2014, p. 35), and the reference to harassment in the Employment Equity Act includes, among other things, sexual harassment, which implies that sexual harassment is a form of unfair discrimination (Gule, 2005, p. 66; Du Plessis and Fouche, 2012, p. 108). The Amended Code of Good Practice on the Handling of Sexual Harassment Cases in the Workplace (GN 1357 of 2005, item 3) also states that sexual harassment is a form of unfair discrimination. Thus, if sexual harassment, being a form of unfair discrimination, takes place in the workplace, it would be a violation of chapter 2 of the Employment Equity Act. Harassment may be regarded as discriminatory, particularly as it serves as an arbitrary barrier to the full and equal enjoyment of an individual's rights in the employment environment (Mukheibir and Ristow, 2006, p. 246).

\subsubsection{Sexual harassment in the workplace: The code of good practice}

At this juncture, it is necessary, for the sake of clarity, to establish the nature and scope of sexual harassment in the workplace. Although the foundation of the prohibition on sexual harassment flows from the Employment Equity Act, it is the Amended Code of Good Practice on the Handling of Sexual Harassment Cases in the Workplace (GN 1357 of 2005) that sheds light on this issue. Item 3 of the Code states that sexual harassment in the employment environment amounts to unfair discrimination and is prohibited on the grounds of sex, gender and sexual orientation (or a combination of such grounds). Item 4 of the Code defines sexual harassment as "unwelcome conduct of a sexual nature that violates the rights of an employee and constitutes a barrier to equity in the workplace". This is qualified by certain factors that have to be taken into account when establishing sexual harassment, namely (1) whether the harassment is on the prohibited ground of sex, gender or sexual orientation (or a combination of such grounds); (2) whether the sexual conduct was unwelcome; (3) the nature and extent of the sexual conduct, and (4) the nature and extent of the effect of such conduct on the employee (GN 1357 of 2005, item 4).

\subsubsection{Employer liability under the Employment Equity Act: Section 60}

In so far as employer liability is concerned, the position under the Employment Equity Act is slightly different from that under the common law. An employee who has been subjected to sexual harassment in the workplace may institute action against the employer under the Employment Equity Act, or the employee may attempt to hold the employer vicariously liable and bring an action for damages in the civil courts. An employer who is sued under the Employment Equity Act may escape liability in terms of section 60(3), as mentioned above, if it can prove that reasonable steps were taken to curb the harassment. (Grogan, 2014, p. 134) Grogan (2014, p. 134) states that this not necessarily constitutes a defence under the common law, since an employer will be held vicariously liable if the perpetrator employee was acting in the course and scope of his/her duty (or even if the employee deviated from his/her normal duties, but the offence and the employee's position were related). 
Employer liability in terms of section 60 above is aimed at penalising employers who do not address equity in the workplace and do not remedy harm caused in the delictual sense (Le Roux, Rycroft and Orleyn, 2010, p. 130). It is therefore more appropriate to view this section 60 employer liability as a form of direct liability, and not as a species of statutory vicarious liability (Le Roux et al., 2010, p. 130, with reference to Mokoena v Garden Art (Pty) Ltd, 2008, and Potgieter v National Commissioner of the SAPS, 2009; Le Roux, 2006, p. 414). To avoid confusion, it is suggested that this view held by Le Roux and colleagues be preferred, even though the court in Piliso vs Old Mutual Life Assurance Co (2007, at 903[15]) stated that this section "clearly is intended to create statutory vicarious liability". Section 60 applies in certain circumstances, which Le Roux and colleagues (2010, p. 131) (from the case of Mokoena v Garden Art (Pty) Ltd, 2008) set out as follows: (1) The conduct must be by an employee of the employer; (2) the conduct must constitute unfair discrimination (sexual harassment); (3) the conduct must occur while at work; (4) the conduct must immediately be brought to the employer's attention; (5) the employer must be aware of the conduct; (6) the employer must fail to consult with all the relevant parties or to take adequate steps to eliminate the conduct (or to otherwise comply with the Employment Equity Act), and (7) the employer must indicate that it did all that was reasonably necessary to ensure that the employee would not act in contravention of the provisions of the Employment Equity Act.

This section will only apply if the perpetrator is an employee, which constitutes a limitation for employees who suffer sexual harassment by third parties not employed by the employer. ${ }^{59} \mathrm{Also}$, if an employer engages in conduct that amounts to sexual harassment, that employer is directly liable in terms of section 6(1) of the Employment Equity Act, and not in terms of section 60 (Le Roux et al., 2010, p. 131-132). A further limitation for employees who wish to hold an employer liable in terms of section 60 , is that the victim employee must have immediately brought the conduct to the employer's attention. Le Roux and colleagues (2010, p. 133) argue (in light of the judgement in Ntsabo v Real Security CC, 2003) that the appropriate standard to measure what is meant by "immediately" will depend on what is reasonable in each specific case.

An employer may also escape liability in terms of section 60 if it can successfully allege one (or both) of the defences contained in that section. The first defence stems from section 60(3), in terms of which an employer will not be held liable if it consulted with all relevant parties and took the necessary steps to eliminate the conduct and comply with the provisions of the Employment Equity Act. According to Le Roux and colleagues, the employer's response does not need to be "perfect", as various factors will come into play in making a determination (Le Roux et al., 2010, p. 134).63 The second defence is contained in section 60(4), in terms of which an employer will not be held liable if it did everything that was reasonably practicable to ensure that the employee would not act in contravention of the Employment Equity Act. In this regard, Le Roux and colleagues (2010, p. 136) suggest that an effective yardstick to determine whether an employer did all that was reasonably practicable is whether the employer implemented employment policies to address sexual harassment in the workplace and made an attempt to educate employees on sexual harassment issues. It is also not a requirement for an employer to have taken "every possible step" to prevent the harassment, but only to have taken "reasonably practicable steps" (Le Roux et al., 2010, p. 137).

According to Le Roux and colleagues (2010, p. 139), an employer may therefore escape liability for an act of sexual harassment in the context of section 60 if the employer can successfully prove that the perpetrator of the sexual harassment was not an employee; the victim of the sexual harassment was not an employee; the conduct did not amount to sexual harassment; the harassment did not occur at work; the victim did not immediately bring the conduct to the employer's attention; the employer consulted with all relevant parties and took the necessary steps to eliminate the conduct and ensure compliance with the Employment Equity Act, and the employer did all that was reasonably practicable to ensure that its employees would not engage in acts of sexual harassment.

\subsection{Common-law vicarious liability in the modern workplace}

The common law has been subject to significant evolution since the enactment of the Constitution of the Republic of South Africa, 1996, of which section 39 allows the judiciary to develop the common law and bring it in line with the Constitution ( $K V$ Minister of Safety and Security, 2005). The common-law doctrine of vicarious liability has not escaped this evolution, and has been interpreted by the courts to extend to instances of sexual harassment (Grobler v Naspers, 2005).69 An employer's liability in terms of the Employment Equity Act does not eliminate the vicarious liability of the employer under the common law (Mukheibir and Ristow, 2006, p. 246), since the Employment Equity Act (55 of 1998) does not contain a provision that suggests that if an employee pursues a claim under the act, he or she may not proceed against the employer in terms of the law of delict (Le Roux et al., 2010, p. 139). The reason for this, according to Le Roux and colleagues (2010, p. 139), is that the common law

59 This limitation will be referred to below in the discussion of Piliso v Old Mutual Life Assurance Co (SA), 2007.

63 One such consideration is whether the employer is a large business with adequate resources to deal with a complaint of sexual harassment. 69 Although the issue of vicarious liability was left open by the Supreme Court of Appeal in Media 24 v Grobler, 2005. 
aims to address unlawful conduct, while the Employment Equity Act seeks to address unfair discrimination. An employer may be held both vicariously and directly liable for an act of sexual harassment in terms of the common law (Mukheibir and Ristow, 2006, p. 247). A victim is also entitled to claim both patrimonial and non-patrimonial loss from the employer, depending on the circumstances (Mukheibir and Ristow, 2006, p. 247). In order for a delictual claim of direct or vicarious liability to succeed against an employer, the elements of a delict have to be proven.

Three requirements must be satisfied in order to hold an employer vicariously liable for the delict of its employee, namely that (1) there must be an employer-employee relationship at the time when the delict is committed; (2) the employee must commit a delict, and (3) the employee must act within the scope of his employment when the delict is committed (Neethling et al., 2010, 366-368). Thus, in light of these requirements, an employment relationship must exist between the employer and the employee at the time when the sexual harassment occurs; the perpetrator employee must intentionally (or negligently) engage in a wrongful act (amounting to sexual harassment), which causes another to suffer damage, and such act of sexual harassment must be committed within the scope of the employee's employment.

In order for a determination that an employee indeed acted within the scope of employment, the employee must not have disengaged him or herself completely from employment and must not have promoted his or her own objectives or interests exclusively (Neethling et al., 2010, p. 368). This requirement has been the cause of great contention in vicarious liability cases, as the case law below will indicate. The test to establish whether the employee acted within the scope of employment was formulated in Minister of Police $v$ Rabie (1986) and comprises both a subjective and an objective component:

It seems clear that an act done by a servant solely for his own interests and purposes, although occasioned by his employment, may fall outside the course or scope of his employment, and that in deciding whether an act by the servant does so fall, some reference is to be made to the servant's intention ... The test is in this regard subjective. On the other hand, if there is nevertheless a sufficiently close link between the servant's acts for his own interests and purposes and the business of his master, the master may yet be liable. This is an objective test. And it may be useful to add that according to the Salmond test ... "a master ... is liable even for acts which he has not authorized provided that they are so connected with acts which he has authorized that they may rightly be regarded as modes - although improper modes - of doing them ...".

The Constitutional Court in $K V$ Minister of Safety and Security (2005, at 32) explained this test in the following manner:

The approach makes it clear that there are two questions to be asked. The first is whether the wrongful acts were done solely for the purposes of the employee. This question requires a subjective consideration of the employee's state of mind and is a purely factual question.

Even if it is answered in the affirmative, however, the employer may nevertheless be liable vicariously if the second question, an objective one, is answered affirmatively. That question is whether, even though the acts done have been done solely for the purpose of the employee, there is nevertheless a sufficiently close link between the employee's acts for his own interests and the purposes and the business of the employer. This question does not raise purely factual questions, but mixed questions of fact and law. The questions of law it raises relate to what is "sufficiently close" to give rise to vicarious liability. It is in answering this question that a court should consider the need to give effect to the spirit, purport and objects of the Bill of Rights.

This test established in Minister of Police $v$ Rabie, Neethling (2011, at 191) explains, shifts the emphasis from the nature of the employee's intention, to the nature of the link between the employee's work and conduct, to the primary question of whether this conduct falls within the boundaries of the risk created by the employer.

In order to hold an employer directly liable for sexual harassment in terms of the common law, the complainant needs to establish the elements of a delict on the employer's part. In most instances, direct liability results from an employer's omission to take sufficient precautions to prevent the harassment, or to take the necessary steps to respond to a victim's claim (Mukheibir and Ristow, 2006, p. 249). According to the Constitutional Court in $F V$ Minister of Safety and Security (2013, at 112), it is appropriate to develop direct rather than vicarious liability on the employer's part in terms of constitutional values.

In cases of sexual harassment, the damage that an individual suffers and that gives rise to a claim of patrimonial and non-patrimonial loss is psychological in nature. In this regard, the victim needs to suffer a recognised psychiatric injury (Mukheibir and Ristow, 2006, p. 251). This differs from the position of employer liability under section 60 of the Employment Equity Act, which does not require a victim to suffer any "minimum damage", such 
as a recognised psychiatric injury - the issue at stake simply is whether the sexual harassment took place or not (Mukheibir and Ristow, 2006, p. 257). Mukheibir and Ristow (2006, p. 251) convincingly argue that a victim of sexual harassment should be entitled to legal recourse under the common law in the absence of such a psychiatric injury, and that an infringement of the victim's right to dignity should serve as the basis for a claim for satisfaction in terms of the actio iniuriarum.

\subsection{The evolution of employer liability in the South African employment realm: A medley of cases}

An overview of relevant case law proves useful to adequately demonstrate the development of employer liability for acts of sexual harassment committed by employees. Various cases that have affected development in this regard are discussed in the following paragraphs. ${ }^{85}$

In one of the pioneering cases involving sexual harassment in South Africa, namely $J v M$ Ltd (1989), the court recognised that employers are saddled with a duty to ensure that their employees are not subjected to sexual harassment in the workplace $(J v M L t d, 1989$, at 758). The court noted that victims of sexual harassment are subjected to humiliation and embarrassment, which creates an intimidating and hostile work environment for employees, as well as that the psychological effect of sexual harassment on employees can be severe and affect their emotional and psychological well-being (at 758). Although this case did not deal with employer liability for acts of sexual harassment, it still is significant, because it highlights that an employer has a duty to ensure that employees are not sexually harassed, and demonstrates that sexual harassment inflicts psychological harm on its victims. This is particularly relevant, as it constitutes the type of damage required when determining the vicarious liability of an employer for acts of sexual harassment by an employee in terms of the common law.

In the case of Intertech Systems (Pty) Ltd v Sowter (1997), the Labour Appeal Court stated that as far as the issue of sexual harassment in this matter was concerned, the employer's conduct towards the employee had been "reprehensible" and that the employee was entitled to compensation for the invasion of her dignity and her employment security (Intertech Systems (Pty) Ltd v Sowter, 1997, at 167). The recent case of Gaga v Anglo Platinum Ltd (2012) also illustrated the employer's duty to prevent its employees from being subjected to sexual harassment, which often has negative consequences such as embarrassment, humiliation, demoralisation and a decline in work performance (Gaga v Anglo Platinum Ltd, 2012, at 334 [9]). This case furthermore illustrated that even where the conduct does not offend an employee, or the employee ignores it, it may very well still result in a finding of sexual harassment (at 342[39]). The court held that even though the complainant did not suffer psychological trauma in this instance, the sexual harassment still constituted an affront to her dignity (at 347[49]).

Although it does not involve vicarious liability, the matter of MEC for the Department of Health, Free State $v$ De Necker (2014) also has relevance. In this case, a non-employee raped a medical doctor while at work (MEC for the Department of Health, Free State v De Necker, 2014, at 3[3]). The doctor instituted a common-law claim for damages against the Member of the Executive Committee (MEC) for Health, for having failed to provide her with a safe working environment (at 3[3]). The MEC alleged that the employee's common-law claim was precluded by a claim in terms of section 35(1) of the Compensation for Occupational Injuries and Diseases Act 130 of 1993 (COIDA) (at 2[1]). The Supreme Court of Appeal held that the rape of a doctor by an outsider did not arise from the doctor's employment and that the risk of being raped was not incidental to such employment position (at 18[32]). The court further stated, however, that to restrict employees to the legislative requirement in COIDA would send an unacceptable message to employees, namely that they are precluded from suing their employer in terms of the common law when the employer fails to provide reasonable protective measures against rape in the workplace, especially since rape is an inherent risk in the South African employment arena (at 19[33]). Fastforwarding to the very recent MEC for Health, Free State $v$ DN (2015), the court similarly found that a commonlaw claim against an employer for damages suffered where a third party rapes an employee in the workplace is not precluded by section 35(1) of COIDA. The judge remarked as follows (MEC for Health, Free State v DN, 2015, at $12[33])$ :

I can understand that courts have strained to come to the rescue of particularly impecunious individuals and have held them entitled to claim compensation from a fund established for that purpose. ... Dealing with a vulnerable class within our society and contemplating that rape is a scourge of South African society, I have difficulty contemplating that employees would be assisted if their common law rights were to be restricted

Although "bodily integrity" is not properly defined in South African law, the corpus consists of both the physical and the mental. The Constitution (1996, s 12(2)) distinguishes between the psyche and the physical body, as it

85 Since some of these cases involve rape, it is important to note that item 5.3.1.1 of the Code of Good Practice explicitly mentions rape as a form of conduct that amounts to sexual harassment. 
mentions both bodily and psychological integrity. The Protection from Harassment Act 17 of 2011 (s 1) clearly considers harassment as an incorporation of any "mental, psychological, physical or economic harm" caused.

However, returning to the development of vicarious liability in South African case law, the first case that resulted in a true paradigm shift was that of $K V$ Minister of Safety and Security (2005). In this matter, a woman instituted an action for damages against the Minister of Safety and Security after she was raped by three policemen $(K V$ Minister of Safety and Security, 2005, at 1-5). The incident occurred in the early hours of the morning after she had accepted a lift home from the police officers, who were in uniform and on duty at the time (at 1-5). The High Court and the Supreme Court of Appeal both dismissed the applicant's claim, after which she appealed to the Constitutional Court (at 8-9). The applicant's primary submission was that if the Minister could not be held vicariously liable for the rape in terms of the ordinary common-law rules, the rules should be developed in light of the spirit, purport and objects of the Bill of Rights (at 14). The applicant also contended that in developing the common-law doctrine of vicarious liability, the applicant's constitutional rights to freedom and security of the person, dignity, privacy and substantive equality should be taken into account (at 14). The Constitutional Court identified that "as long as the employee is acting within the course and scope of his or her duty or is engaged with the affairs of his master ... the employer will be held liable" (at 24). Complications arise when an employee deviates from the normal performance of his or her duties, where it is hard to say whether the employee is still acting within the course and scope of his employment (at 25). In developing the common-law test in Minister of Police $v$ Rabie (1986) discussed above, the court held that an employee may be committing a delict for his or her own purposes (in this case, the rape of the applicant) and simultaneously neglect to fulfil his or her duties as an employee (in this case, omitting to perform their duties as policemen) (at 48). The court further held that the police officers clearly did not rape the applicant on the Minister's instruction, nor did they further the Minister's purposes and obligations when they did so. Subjectively viewed, they were therefore acting entirely in pursuit of their own interests. However, seen against the backdrop of the Constitution, the conduct of the policemen was seen to be sufficiently close to the employer's business to render the Minister liable, as, when viewed objectively, it was not unreasonable for the applicant to place her trust in the policemen, given their statutory duty to prevent crime and protect members of the public as well as the fact that they were in uniform and offered to assist her (at 51-53). Another significant conclusion that the court reached was that the opportunity to commit the wrong would not have arisen if it were not for the police officers' employment positions, and as such, the Minister was found to be vicariously liable (at 57).116 The court stated that the finding of vicarious liability obviated the need to consider the Minister's direct liability (at 58).

The second ground-breaking case that helped develop the doctrine of vicarious liability is $F_{V}$ Minister of Safety and Security (2013). This matter concerned a 13-year-old girl who was raped by a policeman while he was on standby duty ( $F_{V}$ Minister of Safety and Security, 2013, at 1,5). This is an important consideration, as he was not in uniform and was using an unmarked police vehicle at the time, as opposed to the facts in $K V$ Minister of Safety and Security discussed above (at 9). However, since the policeman was on standby, and not completely off duty, the employer could at any time during that night have called upon him to respond to any crime-related incident, and in fact provided him with a police vehicle so that he could discharge any police functions possibly required of him (at 9). He was also being remunerated according to the prescribed hourly tariff for standby duty, and the vehicle was furnished with a police radio (at 9). Although the applicant was suspicious of the man's intentions, she trusted him precisely because he was a police officer (at 10). Although the High Court upheld the applicant's claim, the Supreme Court of Appeal reversed this (at 17-19). The Constitutional Court eventually recognised that the parameters of common-law vicarious liability should be developed in accordance with the Bill of Rights (as was done in $K v$ Minister of Safety and Security) (at 43). In applying the deviation test established in Minister of Police $v$ Rabie (1986) and applied in KV Minister of Safety and Security (2005), the court in this case determined that the policeman did not rape the applicant in the promotion of his employer's constitutional mandate, nor did the Minister order him to rape the applicant (at 51). However, although the policeman was on standby and made use of an unmarked police vehicle, the court argued, the police vehicle facilitated the rape, and his duty to protect the public still applied, even though he was on standby only (at 80). The court was therefore satisfied that a sufficiently close link existed between the policeman's conduct and the employer's business to render the employer vicariously liable (at 80). Neither of the parties raised the issue of direct liability, so the court did not deal with it (at 83). In light of this decision, Neethling (2011, p. 191) states that as a general guideline, employers should be held liable for delicts committed by their employees if their employment position and work conditions enabled them to commit the delict.

Another significant case in the development of employer liability for sexual harassment by an employee is Ntsabo v Real Security CC (2003). A male superior perpetually sexually harassed a female security guard, which eventually resulted in an incident of sexual assault (Ntsabo v Real Security CC, 2003, at 2343). After some

116 This decision of the Constitutional Court has received support, particularly the court's considerations in ascertaining whether a sufficiently close relationship existed between the parties (e.g. Neethling, 2011, p. 189). 
contention, the court established that the applicant, as well as various other parties on her behalf, had indeed informed the employer of the sexual harassment (at 2344). The complainant further alleged that her complaints were not attended to and the intolerable situation forced her to resign (at 2344). As a result of the harassment and assault, the complainant developed several psychological problems, including depression and post-traumatic stress disorder, which eventually saw her being admitted to a psychiatric hospital (at 2347). The employer's failure to address the employee's complaints contributed to the harm she suffered, since she felt that her dignity and privacy were not being respected (at 2347). In determining the employer's liability for the employee's sexual harassment in terms of section 60 of the Employment Equity Act, the court found that the requirement that the employer had to be informed "immediately" should be taken to mean that the employer must be informed within a reasonable time following the incident (at 2373). As the employee did report the incident within a reasonable time in the court's view, she did not fall foul of the Employment Equity Act (at 2374). The court also held that the employer contravened section 60 of the Employment Equity Act, as one of its employees perpetrated the acts of sexual harassment while at work, and that once brought to its attention, the employer failed to attend to the complaint (in terms of section 60(2) of the Employment Equity Act) (at 2377). According to the court, section 60 and section 6(1) of the Employment Equity Act support each other, and where an employer condones or allows conduct, either directly or indirectly, it results in a violation of the Employment Equity Act and vicarious liability on the part of the employer for damages resulting from such conduct (at 2382). The Employment Equity Act imposes a duty on all employers to protect their employees against offensive conduct, the failure of which constitutes a disregard for the law (at 2384). As a result, the court in this case found the employer to be liable for the complainant's damages resulting from the sexual harassment perpetrated by one of its employees (at 2382).

The matter of Grobler $v$ Naspers BPK (2004) is regarded as a watershed case on the issue of an employer's vicarious liability for acts of sexual harassment committed by an employee. In this case, an employee was subjected to sexual harassment by her superior over several months, which eventually resulted in the employee's emotional breakdown (Grobler v Naspers BPK, 2004, at 224). The employee alleged that the employer failed in its duty to provide her with a safe working environment and was therefore vicariously liable for the sexual harassment, since there was a sufficiently close link between the employer's business and the perpetrator employee's conduct to render the employer liable (at 224). The court noted that the doctrine of vicarious liability had been adapted from time to time to conform to a changing society and that an employer does create the risk of suffering damages when he or she establishes and operates a business (at 277-278). In terms of the fundamental question of whether the unlawful conduct was sufficiently connected to the conduct the employer authorised, the court argued that the significant relationship between the perpetrator employee and the victim employee, as well as the consequent risk created or escalated by the unlawful conduct, represented a sufficient connection to impose vicarious liability (at 286). Therefore, the court found that the employer was vicariously liable for the sexual harassment perpetrated by one employee against another (at 298). It further held that if the doctrine of vicarious liability was not flexible enough to deal with sexual harassment, it should be adapted in light of the Constitution to protect the fundamental rights to personal dignity, freedom and security of the person and the bodily and psychological integrity of women in the workplace (at 298).

The appeal against the above decision, in Media $24 \mathrm{v}$ Grobler (2005), is equally relevant to this discussion. The Supreme Court of Appeal declared that the employee indeed suffered sexual harassment (Media $24 \mathrm{v}$ Grobler, 2005, at 34[55]). In terms of the common law, the court said, employers owe their employees the duty to take reasonable care of their safety, which duty is not limited to protection from physical harm only, but also from psychological harm, which may manifest in the form of sexual harassment (at 38[65]-39[65]). The court further argued that the community's legal convictions demand that an employer take reasonable steps to prevent sexual harassment in the work environment, and consequently compensate a victim should such harassment take place (at $41[68]$ ). In this instance, the employer was found to have breached this common-law duty, and was consequently liable (at 43[71]).

In the matter of Sahara Computers (Pty) Ltd v Mokone (2014), an employee was persistently subjected to sexual harassment by a co-worker, and her employer did not take any steps to alleviate the harassment, nor provided her with a safe working environment (Sahara Computers (Pty) Ltd v Mokone, 2014, at 1,2). Not attempting to hold her employer vicariously liable, the aggrieved employee instead opted to institute action against the employer based on the employer's wrongful and negligent omission to provide a safe working environment (at 4). The action against her employer was based on mental anguish, psychological trauma and an impairment of her dignity (at 1,2). The court held that the employer was liable in the circumstances, which was upheld on appeal (at 23, 30, 31).

The thorny issue of the sexual harassment of employees by non-employees or an anonymous third party is reflected in the case of Piliso v Old Mutual Life Assurance Co (2007), where an unknown individual(s) sexually harassed an employee, which caused her psychological trauma (Piliso v Old Mutual Life Assurance Co, 2007, at 
900[1], 900[2]). She informed management, who failed to attend to her complaints (at [900[2]). The employee then elected to claim damages from her employer in terms of section 60 of the Employment Equity Act, or alternatively, in terms of common-law vicarious liability, or alternatively, for the violation of her constitutional right to fair labour practices contained in section 23 of the Constitution (at 900[3]). Since it could not be determined whether the perpetrator was on the employer's establishment as required by section 60 of the Employment Equity Act and common-law vicarious liability, these claims failed (at 905[24], 906[29]). The court did however find that the aggrieved employee was entitled to constitutional damages, as the employer failed to meet its minimum obligations in terms of the employee's right to fair labour practices. The community's legal convictions, the court argued, obligate an employer to launch an investigation to try and find the perpetrator, even where the perpetrator's identity is unknown (at 923[78]). The court further held that the employer should have taken steps to ascertain the extent of the psychological trauma the employee potentially suffered due to the harassment and to provide the employee with counselling (at 923[79]). The employer also had a duty to take all reasonable steps to eliminate or, at least, reduce the possibility of the harassment reoccurring (at 923[80]). As the employer failed in all three these instances, it fell short of the minimum fair labour practice requirements (at 924[80]). This case demonstrates that the court may use its discretion and apply the Constitution (1996) in instances of uncertainty and for want of another remedy.

Interestingly, contrary to the above decision, the High Court, Supreme Court of Appeal and Constitutional Court have held in a number of judgements that litigants may not rely directly on a constitutional right where that right is embodied in other legislation (see SANDU V Minister of Defence, 2007, at [51]). According to the Constitutional Court, where such legislation does not provide a remedy, the correct procedure would be to challenge the legislation as falling short of the constitutional standard. A litigant may then only bypass that legislation if he or she can show that it is unconstitutional or inadequate (Calitz, 2009, p. 408). There is no precedent in South African law for these types of situations. As other jurisdictions such as the United States, United Kingdom and Australia are developing their laws to accommodate these circumstances and find just solutions, so too should South African lawmakers conduct more research to develop the country's legal system to offer appropriate remedies (Calitz, 2009, p. 417, 420).

Another interesting observation is that, in a seemingly new trend in the South African labour arena, not many reported cases of sexual harassment of employees in the workplace lead to delict-based civil action against the employer. ${ }^{173}$ In Nkadimeng and Omega Risk Solutions (Pty) Ltd (2012, at 1748), for example, the harasser was dismissed at an internal hearing, and a monetary award was issued as compensation for a procedural irregularity, but no indication could be found that the victim proceeded to hold the employer liable in delict, even though the sexual harassment occurred at the workplace, involved more than one complainant and was persistent. The complainant in Makoti v Jesuit Refugee Services SA (2012) decided not to tell her employer about the sexual harassment immediately, whilst she was still on the employer's establishment, but only did so later when her allegedly unfair dismissal appeared before the Council for Conciliation, Mediation and Arbitration. Although she lodged a claim for damages based on discrimination in terms of section 60 of the Employment Equity Act, the court did not award damages, despite acknowledging that she would have been entitled to such a claim. Her claim failed merely because she did not inform her employer about the sexual harassment immediately, and the sexual harassment came to the employer's attention only after the non-renewal of her contract, which formed the basis of her unfair dismissal claim (Makoti v Jesuit Refugee Services SA, 2012, at 1724).

\subsection{The legal position in the United States of America}

As a point of departure, it is significant to note that according to the Equal Employment Opportunity Commission (EEOC), ${ }^{177}$ even though the total number of complaints filed with them has decreased gradually since 1997, the number of complaints received from men is increasing ("Sexual harassment in the workplace", 2010). There are two types of sexual harassment in the USA, namely quid pro quo sexual harassment and the creation of a hostile work environment. The former can only be perpetrated by a supervisor, while the latter can be perpetrated by a supervisor or a co-worker (Duffy and Middlemiss, 2002, p. 270).

According to the EEOC, in applying the principles of Title VII of the United States Civil Rights Act of 1964, namely that "it shall be unlawful employment practice for an employer to discriminate against any individual", an employer is responsible for his acts and those acts of his agents and supervisors in respect of sexual harassment, regardless of whether those acts were authorised, previously complained of, forbidden or even if the employer

173 For corporate liability in cases of criminal conduct such as rape, which is also a form of sexual harassment, see Van der Bijl, 2014, p. 760-775.

177 A body especially created to deal with issues such as workplace harassment. 
knew or should have known about the acts (Duffy and Middlemiss, 2002, p. 271). The American courts have applied these EEOC guidelines in holding employers vicariously liable in various scenarios. ${ }^{182}$

With regard to "hostile working environment" harassment, the Supreme Court of America in the matter Meritor Savings Bank FSB vs Vinson (1986) agreed with the EEOC that Congress intended the courts to use the agency principles in these scenarios. The agency principles form part of common law, and state that "under traditional principles of agency, employees act as their employers' agents when their actions fall within their scope of employment". This means that if employees sexually harass co-workers within the scope of their employment, the employer will be held vicariously liable (Duffy and Middlemiss, 2002, p. 256). However, even if the employee is not acting within the scope of his or her employment, an employer can indeed be held liable for its employee's actions in four sets of circumstances (American Law Institute, 1958, p. 282, 611), namely if the employer intended the consequences; if the employer was negligent; if the conduct violated a non-delegable duty, and if an apparent authority standard exists.

The lower courts in the United States apply various standards in terms of the Restatements of the Law treatises. One of the dominant standards used is the "knew or should have known" standard, which the EEOC also recommends (McCarter, 2009, p. 8). This standard has however been criticised, as it could mean that "the employer is virtually able to ignore the possibility of workplace harassment until it is reported" (Duffy and Middlemiss, 2002, p. 277), and led to unsatisfactory decisions in cases such as Blankenship vs Parke Care Centers $\operatorname{Inc}(1997)$.

In Burlington Industries Inc vs Ellerth (1998), the court had to decide whether they could hold an employer strictly liable for the actions of a supervisor who sexually harassed a female employee on various occasions. The employee did not report this to management, even though the employer had a sexual harassment policy for the workplace. The employee eventually resigned as a result of the harassment, which the court saw as a tangible employment action, and the employer was held strictly liable for the supervisor's actions. If there was no tangible employment action, the employer could have raised the existing sexual harassment policy as an affirmative defence (Burlington Industries Inc vs Ellerth, 1998; Lindstrom, 2010, p. 112-114; F Renee Nelson v City of Lake Charles, 2013, at 3-4). The Burlington judgement has been praised not only because it encourages employers to implement and enforce sexual harassment policies, but also spurs employees to report incidents of sexual harassment (Gearty, 2009, p. 399). However, on the negative side, the decision sets a precedent to hold employers strictly liable for sexual harassment by supervisors, even if the employer acted reasonably and had a sexual harassment policy (Joubert, Van Wyk and Rothmann, 2011)192 in place (Scott, 1999, p. 172; McCarter, 2009, p. 8). The matter indeed opened the floodgates to employer liability (Scott, 1999, p. 179).

Regarding the employer's liability for sexual harassment by non-employees, the EEOC (Guidelines on Discrimination Because of Sex, part 1604, s 11(e), title 29) says:

An employer may also be responsible for the acts of non-employees, with respect to sexual harassment of employees in the workplace, where the employer (or his agents or supervisory employees) knows or should have known of the conduct and fails to take immediate and appropriate corrective action.

This means that employers can steer clear of liability if they have taken appropriate action. In the matter of Folkerson vs Circus Circus Enterprises Inc. (1997), an employer indeed successfully defended a claim of harassment of an employee by a non-employee because the employer had taken "remedial corrective action" once he became aware of the harassment (Calitz, 2009, p. 411).

The position regarding employer vicarious liability for sexual harassment of employees in the United States therefore seems very clear-cut. The American government has demonstrated its principled stance on the matter by implementing, through the EEOC, an umbrella of guidelines that are federally based and apply to all American states. In addition, the various pieces of legislation, including the Civil Rights Act of 1964 and the Restatements of the Law treatises, serve as a guideline to judges and lawyers about the general principles of common law. Sorensen (2010, p. 511) offers a different view, however, namely that the legal position in the USA is not as clear as we are led to believe. He states that the second restatement of torts (agency) was in effect repealed by the third restatement of torts pertaining to agency, which would imply that an employer should no longer be held liable by means of vicarious liability where sexual harassment has given rise to a hostile work environment and the employer was unaware of the harassment. This also applies where the employer acts indifferently once informed of the sexual harassment. It is suggested that in both these cases, it should be treated as a form of direct instead of vicarious liability. (Sorensen, 2010, p. 512)

182 See Jamie Quinn v Ron Griffiths; Pipe \& Piling Supplies (USA) Ltd, 2013, at VII(B), where the defence brought by the Ellerth decision was discussed, which requires an employer to exercise reasonable care to prevent sexual harassment.

192 The mere existence of a policy is insufficient and does not guarantee its effectiveness. It needs to be properly implemented. 
The American courts have also taken a no-tolerance approach and have placed the burden on employers to tackle sexual harassment in the workplace.

\subsection{The legal position in Australia}

In Australia also, the position with regard to employers' vicarious liability in workplace sexual harassment cases $^{203}$ is governed by legislation. The most important act in this regard is the Sex Discrimination Act 4 of 1984, which establishes employees' rights and determines when an employer may be vicariously liable. It also states what the powers of the Australian Human Rights Commission (AHRC) are. Section 48 of the act states that the AHRC has the power, amongst others:

(c) to promote an understanding and acceptance of, and compliance with, this Act [the Sex Discrimination Act]; ...

(f) to examine enactments, and (when requested to do so by the Minister) propose enactments, for the purpose of ascertaining whether the enactments ... are ... inconsistent with the objectives of this Act, and to report to the Minister the results of any such examination;

(g) on its own initiative or when requested by the Minister, to report to the Minister as to the laws that should be made by the Parliament, or action that should be taken by the Commonwealth, on matters relating to discrimination on the ground of sex, sexual orientation, gender identity, intersex status, marital or relationship status, pregnancy or potential pregnancy, breastfeeding or family responsibilities or to discrimination involving sexual harassment;

(ga) to prepare and to publish ... appropriate guidelines for the avoidance of discrimination on the grounds [listed above];

(gb) where the Commission considers it appropriate to do so, with the leave of the court hearing the proceedings ... to intervene in proceedings that involve issues of discrimination on the grounds [listed above] ... (Commonwealth Consolidated Acts, n.d.)

Section 106 of the Sex Discrimination Act deals specifically with the doctrine of vicarious liability and reads as follows (Commonwealth Consolidated Acts, n.d.):

(1) Subject to subsection (2), where an employee or agent of a person [employer] does, in connection with the employment of the employee or with the duties of the agent as an agent:

(a) an act that would ... be unlawful under Division 1 or 2 of Part II ...; or

(b) an act that is unlawful under Division 3 of Part II; this Act applies in relation to that person [employer] as if that person had also done the act.

(2) Subsection (1) does not apply ... if it is established that the person [employer] took all reasonable steps to prevent the employee or agent from doing acts of the kind referred to in that paragraph.

The section above bears striking similarities to section 60 of the South African Employment Equity Act, particularly subsection 2. As a result of the powers conferred on it by the Sex Discrimination Act, the AHRC formulated a guide on vicarious liability, in which it states that an employer, regardless of its size, may be legally responsible for discrimination and harassment that occurs in the workplace or in connection with a person's employment, unless it can be shown that "all reasonable steps" have been taken to reduce this liability. However, it fails to define "all reasonable steps", probably as circumstances would vary from case to case (AHRC, n.d., under "Vicarious liability").

According to the AHRC, an employer can be held vicariously liable for the conduct of individual or groups of employees; directors, supervisors or managers; workplace participants; agents; contract workers or persons being paid commission; a partner of a company harassing another partner; members of organisations that grant occupational qualifications; a person employed by a trade union harassing a member, as well as a person operating an employment agency who harasses someone who uses the agency (AHRC, n.d., under "Conduct of persons"). Therefore, the employer in Australia can clearly be held vicariously liable for the conduct of a wide range of people - not only employees. This puts pressure on the employer to take concrete, reasonable preventative measures to avoid liability. In deciding whether preventative action is reasonable, the employer should consider, amongst others, the size and structure of the organisation; the employer's available resources; the nature of the work being done; any gender imbalances in the workplace; employment of women in non-traditional areas; the number of junior staff; the workplace culture; cultural diversity; any history of harassment at the workplace; working hours, and the level of supervision over employees (AHRC, n.d., under "Factors").

203 For further information on recommendations on sexual harassment in employment, see Australian Human Rights Watch, 2008. 
Finally also, the AHRC has developed guidelines for employers to reduce not only harassment in the workplace, but also limit their own vicarious liability. These include the following (AHRC, n.d., under "Reasonable steps"):

- Obtaining high levels of support from the chief executive and senior management to implement a comprehensive strategy to address discrimination and harassment

- Formulating, in consultation with employees and unions, a written policy prohibiting discrimination and harassment

- Consulting relevant parties when formulating anti-discrimination or anti-harassment policies

- Ensuring that the policy is promoted and applied consistently at all levels, as well as translated and explained in various applicable languages

- Ensuring that managers and supervisors discuss and re-evaluate the policy at staff meetings, and that the policy is regularly updated

- Ensuring that the policy and other relevant information on discrimination and harassment are made available to new staff

- Displaying posters and distributing brochures in work areas, raising awareness of sexual harassment and its dangers

- Ensuring that managers are trained to deal with and prevent sexual discrimination, that they maintain a professional standard at all times and are held accountable through established procedures

- Appointing managers who understand how to deal with and prevent sexual harassment, and evaluating their performance in adhering to the policy

- Removing offensive, explicit or pornographic calendars, literature, posters and other materials from the workplace, and prohibiting the inappropriate use of the internet, computers and other technology in the workplace by including a clause to that effect in the policy

As for vicarious liability in the case of sexual harassment by non-employees, the Sex Discrimination Act does not provide for vicarious liability, but the courts seem to have accepted that sexual harassment is a form of unfair discrimination, for which the employer should be held liable as an accessory in terms of section 105 of the act (Calitz, 2009, p. 419).212

Thus, the Australian position regarding employers' vicarious liability seems concrete, with a comprehensive piece of legislation in place, which does not confine the issue to the relevant act alone, but also confers powers on other bodies such as the AHRC to lay down rules and guidelines to deal with the problem.

\subsection{The legal position in Ontario, Canada}

In Ontario, Canada, the contentious issue of sexual harassment in the workplace has prompted the provincial legislature to respond in a firm manner by enacting the Ontario Human Rights Code (RSO 1990, c. H. 19) on 15 June 1962.

The code covers a wide range of issues, including the different types of sexual harassment, the parties affected, preventative and responsive measures, the areas where the code applies, and the employer's vicarious liability (OHRC, n.d., under "Types of sexual harassment").

According to the code, sexual harassment means "engaging in a course of vexatious comment or conduct that is known or ought to be known to be unwelcome" (OHRC, n.d., under "Unwanted conduct"). This can include sexual solicitation and advances, where a person asks for sexual favours in exchange for a benefit; a poisoned environment, with visible pornography in the workplace; gender-based harassment, and violence (OHRC, n.d., under "Sexual harassment"). The code prohibits all forms of sex-based discrimination, including sexual harassment, and applies to the five "social" areas of services, goods and facilities; housing; contracts; employment, and membership of vocational associations such as trade unions (OHRC, n.d., under "Prohibition on sex discrimination").

The code places a legal obligation on all organisations and institutions in Ontario to take steps to prevent and respond to sexual harassment. Employers, housing providers, educators and other parties must ensure that their environments are free of poisonous influences and that they respect human rights. Should parties contravene the code by ignoring complaints of sexual harassment, they will be held liable for the harm or damage they themselves or their employees may cause (OHRC, n.d., under "Preventative steps").

212 No legal tie is required between the harasser and the employer. 
In deciding whether an organisation has fulfilled its obligations to respond to a complaint, factors taken into account will include the available procedures to deal with discrimination and harassment; the time it took the organisation to respond to the complaint; whether the complaint was taken seriously; the resources made available to deal with it; whether the organisation catered for a healthy environment for the affected person, and how well informed the victim was about the actions that could have been taken (OHRC, n.d., under "Antidiscrimination policy").

The code states that an employer can prevent sexual harassment and limit liability by formulating and implementing an anti-discrimination policy that informs all parties of their rights, roles and responsibilities, and by clearly stating in such policies that sexual harassment will be dealt with quickly and effectively. Everyone in the workplace should be made aware of these policies by making the documents available to all persons when they enter employment, including them in workshops and employee orientation, as well as training and educating persons and managers about the policies. (OHRC, n.d., under "Measures to be taken") This is probably where other jurisdictions such as South Africa fail: Employers are reluctant to educate employees on policies and guidelines, and in effect do not protect themselves from vicarious liability nor protect their employees from sexual harassment in employment. The proper implementation of policies cannot be overemphasised. It is a known fact that the adoption of a policy stands separate from its implementation. As such, implementation of any policy or procedure is key to its success. ${ }^{221}$ The mere existence of a policy is not enough (Le Roux et al., 2010, p. 66; Hoel and Einarsen, 2010, p. 47, with reference to Einarsen and Hoel, 2008).

Regarding vicarious liability, section 46.3 of the code states that a corporation, trade union or occupational association, unincorporated association or employers' organisation will be held responsible for discrimination, including acts or omissions, committed by employees or agents in the course of their employment, regardless of whether they had any knowledge or participation or control over these actions (OHRC, n.d., under "Vicarious liability").

According to the code, the so-called "organic theory of corporate liability" may apply. This theory postulates that an organisation may be liable for acts of harassment its employees commit if it can be proven that the organisation was aware of the harassment, or if the harasser was part of the management of that organisation or "directing mind" of the organisation. As managers, supervisors and other decision-makers are generally deemed to be part of the "directing mind", their acts are considered to be the employer's acts. In the same way, employers can be held liable for non-employees' actions. (OHRC, n.d., under "Organic theory") In Bent v Olivia Tile International Inc $(2008$, at 8,9$)$, it was stated that sexual harassment in itself is not a cause of action in the state of Ontario, but that vicarious liability could be a cause of action if it is based on sexual assault. Nothing precluded the victim in this matter from pursuing her claim with the Ontario Human Rights Commission, which she did.

Employers have a duty to ensure a safe and harmless working environment, and to take steps to ensure that sexual harassment does not occur in their workplace. Once they become aware of sexual harassment, they must take immediate action to resolve the situation. If the employer is satisfied that the harassment indeed occurred, he must consider both disciplinary action and further preventative measures that should be taken and implemented, such as training or education. Failure on the employer's part to take these measures and steps will result in the employer being held vicariously liable for the harassment of the employer (OHRC, n.d., under "Employer's duty").

\subsection{Conclusion and recommendations}

As the comparative analysis in the sections above has shown, the United States through its EEOC, Australia through its AHRC, and Ontario, Canada, through its Ontario Human Rights Code have all made great strides in legislating and regulating sexual harassment in the workplace, and enforcing employers' vicarious liability in such instances. Sadly, South Africa does not seem to be on a par with international standards in this regard. It is suggested that this may be remedied in the following ways:

As the South African Commission for Conciliation, Mediation and Arbitration (CCMA) does not keep a record of the number of workplace sexual harassment cases reported, it is difficult to measure the actual magnitude of the problem and take decisive action to control it. For this reason, it would be advisable for South Africa also to hasten towards the creation of a body such as those found in the other three jurisdictions studied in this article. This body should set clear guidelines as to the actions employers need to take in the workplace to prevent sexual harassment and to protect employees. The legislature needs to step up and play an active role in helping to create a South African commission similar to the EEOC or AHRC, which can be tasked specifically to deal with employment issues,

221 For an interesting narrative take on the importance of proper implementation, see Billig, Malkin and Michel, 2011. 
including protecting employees against harassment, and enforcing and raising awareness about employer liability.

Although it is good to have a Code of Good Practice on the Handling of Sexual Harassment Cases in the Workplace, it is clearly not enough for it to merely serve as a guiding document. Employers who fail to strictly adhere to the guidelines in the code face no sanction. The body proposed above should therefore also implement strict measures against employers who fail to implement an anti-discrimination policy in the workplace. In the as yet unreported case of SA Metal Group (Pty) Ltd v CCMA (2014), the Labour Court found an arbitration award that had been made without considering the Code of Good Practice on Handling Sexual Harassment Cases reviewable. The court stressed the importance of adherence to the code, which should serve as an encouragement to employers to adopt their own policies and embark on training about what constitutes sexual harassment, also referring to the guidelines contained in the code.

The drafting of internal policies both prohibiting and managing sexual harassment in employment should be compulsory, and labour inspectors should act decisively in instances of non-compliance. By involving all stakeholders in the process of compiling these policies, employers should ensure that such documents clearly state the established channels for reporting harassment, interim protection and counselling afforded to victims, the type of relief available to victims, and the penalties perpetrators may face. The CCMA has developed a code of good practice, which all employers could easily adopt (CCMA, n.d.).

Awareness drives regarding sexual harassment at work can be a valuable tool. However, it does seem as if government's efforts, including webpages such as "Sexual harassment laws in South Africa" (n.d.), thus far have failed to reach all employers and employees in South Africa, partly as many employees are reading and computer illiterate.

Training for managers to prevent and deal with sexual harassment in the workplace should be compulsory. This may be done in the same way that the adjudicators of specialised courts are trained in the specifics of their particular court. In addition, as the CCMA may now also deal with sexual harassment cases, and training for the commissioners will therefore be compulsory, it is not impossible for managers to be trained also. Training could even count towards, or should in the very least be made compulsory for, employment equity.

South Africa could consider the establishment of a national database with details of all reported cases, the areas or sectors where sexual harassment is more prevalent, the types of workers who are most at risk, the type of person who is likely to engage in unwanted conduct, and the effect of sexual harassment on the victim. Such a database would not only raise awareness of the problem, but will ensure that appropriate action is taken to deal with it. It would furthermore be instructive to various parties in the South African labour arena, including the judiciary, the Department of Labour, the legislature, employers and employer's organisations as well as employees and their trade unions.

Employees need to be encouraged to report cases of sexual harassment, and should be assured of a zero tolerance approach towards perpetrators. Confidentiality needs to be guaranteed until perpetrators have been brought to justice. The threat of an employer being held vicariously or directly liable in these cases will go a long way towards encouraging them to adopt measures to eliminate and curb sexual harassment in the workplace.

Finally, it is vital that the South African courts take a leaf out of the above jurisdictions' book by starting to play a more proactive role in developing the law to set concrete and fixed rules, and ensuring that all loopholes are eliminated. Our courts need to further the objectives of the Constitution more actively, using their discretion to develop the law when faced with, for example, cases of sexual harassment of employees by non-employees, which goes largely unregulated at present. Judicial decisions regarding employer liability for sexual harassment, as well as the various types of employer liability, should be more readily communicated to employers in order to motivate them to do more in the fight against sexual harassment.

Employees are not the only ones who stand to lose a lot where sexual harassment is rife in the employment realm; employers stand to lose just as much if they "fail to create and maintain a working environment free of sexual harassment" (Joubert et al., 2011, p. 313). As employers may face vicarious liability where they fail to both prevent and manage sexual harassment in the workplace, they will be well served to heed the following advice (Joubert et al., 2011, p. 313, with reference to Grogan and Anton, 2004):

It is truly important to acknowledge that the problem does not lie within the individual being harassed, the problem lies within the external forces that perpetuate and enable sexual harassment to exist in a place ... where all are supposed to feel safe. (Shaw, 2011) 


\section{References}

American Law Institute, (1958). Restatement of the Law Second: Agency 2d, vol 1, United States.

Atiyah P, (1967). Vicarious Liability in the Law of Torts, London: Butterworths.

Australian Human Rights Commission (AHRC), (n.d.). Employer Responsibilities: A Guide to Vicarious Liability [Webpage] Retrieved from http://www.humanrights.gov.au

Australian Human Rights Watch, (2008). Australian Human Rights Watch Report on Sexual Harassment at the Workplace in Australia [Report on internet] Retrieved from https://www.humanrights.gov.au/publications/chapter-1-summary-survey-findings-sexual-harassmentserious-business

Billig A, Malkin E, Michel, S, (2011). Sexual harassment at work: Can legal remedies change employer practices? [Webcast recap] Retrieved from https://www.wilsoncenter.org/event/sexual-harassment-work-can-legalremedies-change-employer-practices?gclid=CKCg0rDkzsoCFQaNGwod9ZcPJA

Botha MM, Millard D, (2012). The past, present and future of vicarious liability in South Africa. De Jure, 45(2): $225-253$.

Calitz K, (2005). Vicarious liability of employers: reconsidering risk as the basis of liability. TSAR, (3): 215-235.

Calitz KB, (2009). The liability of employers for the harassment of employees by non-employees. Stell LR, (3): 407-425.

Chicktay MA, (2010). Sexual Harassment and Employer Liability: A Critical Analysis of the South African Legal Position. JAL, 54(2): 283-297.

Commonwealth Consolidated Acts, (n.d.). Sex Discrimination Act [Act on the internet] Retrieved from http://www.austlii.edu.au

Council for Conciliation, Mediation and Arbitration (CCMA), (n.d.). Code of Good Practice on sexual harassment at work [Code on internet] Retrieved from http://www.ccma.org.za/Display.asp?L1=34\&L2=68

Duffy A, Middlemiss S, (2002). Comparative analysis of the vicarious liability of the employers in harassment cases in the United Kingdom and the United States. CLWR, 31(3): 254-285.

Du Plessis JV, Fouche MA, (2012). Practical Guide to Labour Law. $7^{\text {th }}$ ed. Durban: Lexis Nexis.

Du Toit D, Potgieter M, (2014). Unfair Discrimination in the Workplace. Claremont: Juta \& Co.

Gearty LP, (2009). Scope of Faragher-Ellerth Affirmative Defense to Vicarious Liability Not Defined by Employer's Own Sexual-Harassment Policy - Chaloult v. Interstate Brands Corp., 540 F.3d 64 (1 ${ }^{\text {st }}$ Cir. 2008). Suffolk U.L. Review, 42(3): 399-407.

Grogan J, (2014). Workplace Law. 11 th ed. Claremont: Juta \& Co.

Gule S, (2005). Employer' s vicarious liability for sexual harassment. JBL, 13(2): 66-69.

Hoel H, Einarsen S, (2010). Shortcomings of anti-bullying regulations: the case of Sweden. Eur. J. Work. Organ. Psy., 19(1): 30-50.

Joubert P, Van Wyk C, Rothmann S, (2011). The effectiveness of sexual harassment policies and procedures at higher education institutions. SAJHRM, 9(1): 310-320.

Law Teacher, (n.d.). Vicarious liability [Webpage] Retrieved from http://www.lawteacher.net

Le Roux R, (2006). Section 60 of the Employment Equity Act 1998: Will a Comparative Approach Shake this Joker Out of the Pack? Obiter, 27(3): 411-428.

Le Roux R, Rycroft A, Orleyn T, (2010). Harassment in the Workplace: Law Policies and Processes. Durban: Lexis Nexis.

Lindstrom EJ, (2010). All Carrots and No Sticks: Moving Beyond the Misapplication of Burlington Industries, Inc. v. Ellerth. HWLJ, 21: 111-136.

McCarter WD, (2009). Sexual Harassment of Employee By a Company Supervisor Warranted Punitive Damages Against the company. J Mo Bar, 65(1): 8-9.

Mukheibir A, Ristow L, (2006). An Overview of Sexual Harassment: Liability of the Employer. Obiter, 27(2): 245262.

Neyers JW, (2005). A Theory of Vicarious Liability. Alta. Law Rev, 43(2): 1-41.

Neethling J, (2011). Vicarious liability of the State for rape by a police official: regspraak. TSAR, (1): 186-191.

Neethling J, Potgieter JM, Visser PJ, (2010). Law of delict. $6^{\text {th }}$ ed. Durban: Lexis Nexis.

Ontario Human Rights Commission (OHRC), (n.d.). The Ontario Human Rights Code [Code on the internet] Retrieved from http://www.ohrc.on.ca

Oxford Dictionaries, (2014). Vicarious [Entry in online dictionary] Retrieved from http://www.oxforddictionaries.com/definition/english/vicarious

Scott A, (1999). Employers beware! The United States Supreme Court opens the floodgates on employer liability under Title VII. S. Ill. U. L. J., 24: 157-179.

Sexual harassment in the workplace, (2010). [Webpage]. Retrieved from http://www.workharassment.net

Sexual harassment laws in South Africa, (n.d.). [Webpage]. Retrieved from http://www.mywage.co.za/main/women-and-work/sexual-harassment-1 
Shaw E, (2011). Girls for Gender Equity Helps Educators Reflect on Sexual Harassment in Schools [Article on internet] Retrieved from https://nesri.org/news/2011/08/girls-for-gender-equity-helps-educators-reflecton-sexual-harassment-in-schools

Sorensen PT, (2010). A fresh look at employer liability for sexual harassment. T.M. Cooley L Rev, 27: 510-539.

Van der Bijl C, (2014). Corporate assault, bullying and the aegis of criminal law. TSAR, (4): 760-775.

\section{Register of cases}

Bent v Olivia Tile International Inc, CarswellOnt 6040, 169 A.C.W.S. (3 $\left.{ }^{\text {rd }}, 2008\right)$

Blankenship vs Parke Care Centers Inc, 123 F.3d 868 (6th Cir. 1997)

Burlington Industries Inc vs Ellerth, 118 S. Ct. 2257 (1998)

Folkerson vs Circus Circus Enterprises Inc, 107 F.3d 754 (9th Cir. 1997)

F Renee Nelson v City of Lake Charles, U.S District LEXIS 157226 (2013); 120 Fair Empl. Prac. Cas. (BNA) 967 para. 1-6

F v Minister of Safety and Security 20132 SACR 20 (CC)

Gaga v Anglo Platinum Ltd 201233 ILJ 329 (LAC)

Grobler v Naspers 200525 ILJ 439 (C)

Grobler v Naspers BPK 20044 SA 220 (C)

Intertech Systems (Pty) Ltd v Sowter 19972 LLD 166 (LAC)

Jv M Ltd 1989 ILJ 755 (H)

Jamie Quinn v Ron Griffiths; Pipe \&Piling Supplies (USA) Ltd, FED App. 0192 N (6 $6^{\text {th }}$ Cir. 2013); 117 Fair Empl. Prac. Cas. (BNA) 701.

K v Minister of Safety and Security 20056 SA 419 (CC)

Makoti v Jesuit Refugee Service SA 201233 ILJ 1706 (LC)

MEC for Health, Free State v DN 20151 SA 182 ( SCA)

MEC for the Department of Health v De Necker (924/2013) [2014] ZASCA 167 (8 October 2014)

Media 24 v Grobler 20056 SA 328 (SCA)

Meritor Savings Bank FSB vs Vinson 477 US 57 (1986)

Minister of Police v Rabie 19861 SA 117 (A).

Mkhize vs Martins 1914 AD 382

Nkadimeng and Omega Risk Solutions (Pty) Ltd 201233 ILJ 1747 (CCMA)

Ntsabo v Real Security CC 200324 ILJ 2341 (LC)

Piliso v Old Mutual Life Assurance Co 200728 ILJ 897 (LC)

Sahara Computers (Pty) Ltd v Mokone 201435 ILJ 2750 (GP)

SA Metal Group (Pty) Ltd v CCMA (CC50/13) [2014] ZALCCT 15 (15 April 2014)

SANDU v Minister of Defence 20078 BCLR 863 (C)

\section{Register of legislation}

Australia: Act No. 4 of 1984, Sex Discrimination Act 1984 [Australia], 21 March 1984

Civil Rights Act of 1964, Pub.L. 88-352, 78 Stat. 241 (1964) (United States)

Code of Good Practice on the Handling of Sexual Harassment Cases in the Workplace GN 1367 of 1998 , supplemented by GN 1357 of 2005 (South Africa)

Compensation for Occupational Injuries and Diseases Act (COIDA) 130 of 1993 (South Africa)

Constitution of the Republic of South Africa, 1996

EEOC Guidelines on Discrimination Because of Sex (29 CFR Part 1604) (United States)

Employment Equity Act 55 of 1998 (South Africa)

Employment Equity Amendment Act 47 of 2013 (South Africa)

Ontario Human Rights Code, RSO 1990, C. H. 19, 1962

Protection from Harassment Act 17 of 2011

\section{List of abbreviations}

\section{AHRC}

Alta. Law Rev.

CCMA

CLWR

EEOC

Eur. J. Work Organ. Psy. HWLJ
Australian Human Rights Commission

Alberta Law Review

Council for Conciliation, Mediation and Arbitration

Common Law World Review

Equal Employment Opportunity Commission

European Journal of Work and Organisational Psychology

Hastings Women's Law Journal 
ILJ

JAL

JBL

J Mo Bar

OHRC

\section{SAJHRM}

S. Ill. U. L. J.

Stell LR

Suffolk U.L Rev.

T.M. Cooley L Rev

TSAR
Industrial Law Journal

Journal of African Law

Journal of Business Law

Journal of The Missouri Bar

Ontario Human Rights Commission

South African Journal of Human Resource Management

Southern Illinois Law Journal

Stellenbosch Law Review

Suffolk University Law Review

Thomas M. Cooley Law Review

Tydskrif vir die Suid-Afrikaanse Reg 